\title{
Clinical Potential and Putative Risks of Fertility Preservation in Children Utilizing Gonadal Tissue or Germline Stem Cells
}

\author{
KIRSI JAHNUKAINEN, JENS EHMCKE, OLLE SÖDER, AND STEFAN SCHLATT
}

Department of Cell Biology and Physiology [K.J., J.E., S.S.], Center for Research in Reproductive Physiology, University of Pittsburgh, School of Medicine, Pittsburgh, PA 15261; Department of Pediatrics [K.J], University of Turku, FIN-20520 Turku, Finland; Department of Woman and Child Health [K.J., O.S], Pediatric Endocrinology Unit, Karolinska Institute and University Hospital, SE-171 76 Stockholm, Sweden

\begin{abstract}
Rapid progress in the development of novel experimental strategies to generate fertile gametes from cryo-preserved ovarian and testicular tissue motivates oncologists to investigate ways in which gonadal tissue might be preserved. Childhood cancer patients remain the major pediatric group which can benefit from these techniques. Other potential candidates include patients with systemic diseases, which require gonadotoxic chemotherapy, patients undergoing gonadectomy, patients with Turner or Kleinefelter's syndrome, and boys with cryptorchid testes. This review aims to present an overview of the current state of knowledge in experimental germ stem cell transplantation in higher primates including humans, and the clinical risks and limitations related to such procedures in children. This area of research is discussed in the context of the potential future options that may become available for preserving fertility in boys and girls. (Pediatr Res 59: 40R-47R, 2006)
\end{abstract}

$\mathrm{S}^{\mathrm{t}}$ tem cells in the postnatal life of mammals are capable of indefinite self-renewal, i.e. they show low mitotic turnover throughout lifetime without entering differentiation, and produce differentiating daughter cells (1). Most stem cell systems make use of progenitor cells, which usually show high mitotic activity and produce the final differentiated cells needed for tissue homeostasis (2). Thus stem cells, which show higher proliferation only after major pathologic events, act as a regenerative reserve, whereas progenitor cells act as a functional reserve (2). The male germline of non-human primates and humans combines true stem cells, having low mitotic activity, with progenitor cells that produce a high number of differentiating daughter cells in a system ideally suited for maintaining the integrity of the genome, and the daily output of millions of motile sperm; two tasks, which are of key importance, for insuring the transmission of the genome to the next generation, during a reproductive life that spans several decades (Fig. 1).

In females, the current generally accepted view is that oocyte production ceases during fetal development leading to

Received November 16, 2005; accepted November 16, 2005.

Correspondence: Kirsi Jahnukainen, M.D., Ph.D., University of Pittsburgh, School of Medicine, Department of Cell Biology and Physiology, Center for Research in Reproductive Physiology, Pittsburgh, PA 15261; e-mail: Kirsi.Jahnukainen@kbh.ki.se

This work was supported financially by start-up funds provided by Pittsburgh University, NIH-grant (1RO1 01050617-01), The Swedish Children's Cancer Fund, Swedish Research Council (2002-5892), Helsingin Sanomat Centennial Foundation and The Nona and Kullervo Vare Foundation.

DOI: $10.1203 / 01 . p d r .0000205153 .18494 .3 b$ a finite stock of oocytes at birth. Only a few oocytes will be released during ovulation during reproductive life. The majority will be lost due to atretic degeneration, and replenishment of the oocyte pool from germline stem cells does not occur (3-5) (Fig. 1). However, recent reports have challenged this concept. It has been shown that primordial germ cells in culture dishes are capable of forming oogonia and follicle-like structures (6), and that ovarian regeneration may occur from stem cells or arise from stem cells located in the bone marrow (7-9).

\section{CURRENT ADVANCES IN MALE GERMLINE STEM CELL BIOLOGY}

In the male, studies of germ cell biology have traditionally addressed the differentiation of premeiotic germ cells, spermiogenesis, and the interaction of germ and Sertoli cells (10-17). More complex data on non-human primate spermatogonial organization and physiology have only recently been published $(18,19)$. Proliferating spermatogonia in rhesus monkey show a complex pattern of clonal expansion. Differentiating germ cells within these clones are fully synchronized (Fig. 2). We observed that the proliferation of spermatogonia is initiated from small clones and involves clonal splitting to determine whether the cells undergo self-renewal or differentiation.

In mice, it has recently been shown that even primordial germ cells isolated from the embryonic epiblast or teratocarcinoma cells have the potential to function as germline stem cells colonizing the testis and generating male germ cells $(20,21)$. These findings indicate that the testicular microenvironment offers unique niches to germ cells, and that only this unique testicular microenvironment allows germline stem cells to enter the differentiation pathway. This theory is enforced by in vitro findings (22-26).

Abbreviations: ART, assisted reproduction techniques; FACS, fluorescence activated cell sorting 

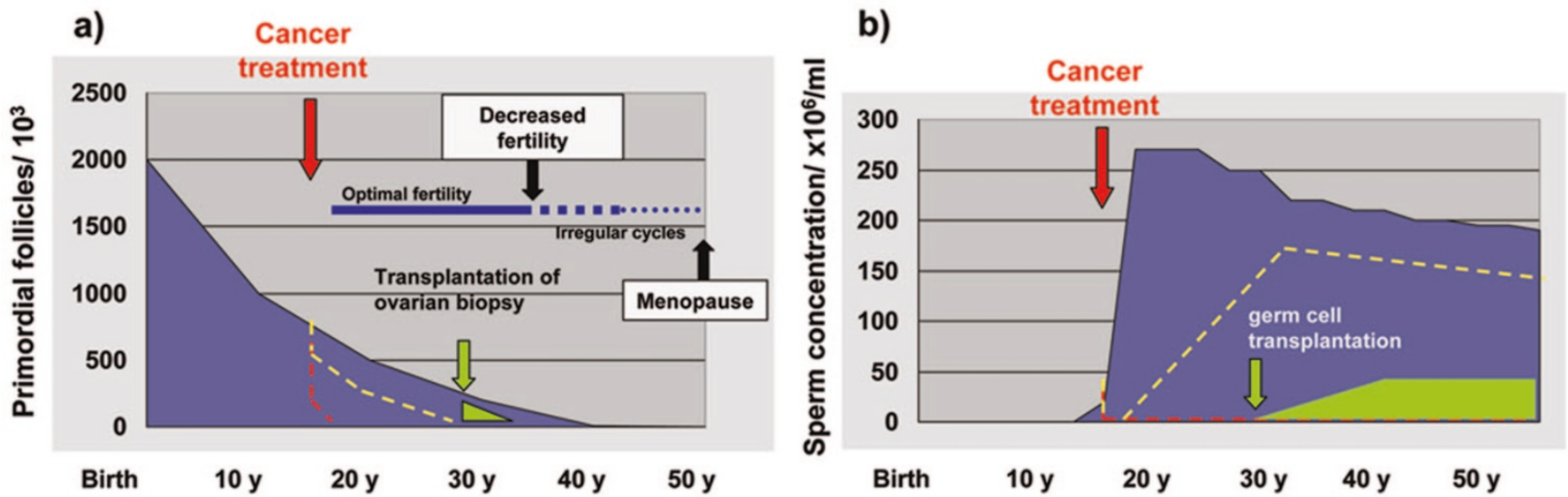

Figure 1. A) Physiologic decline of ovarian reserve and associated fertility consequences. Two possible kinetics of decline in primordial follicles caused by cancer treatment with increasing intensity leading to premature menopause (yellow dotted line) or immediate ovarian failure (red dotted line). B) Mean normal sperm concentration at different ages. Possible kinetic of decline in sperm concentration and slow recovery (yellow dotted line) or lack of recovery (red dotted line) associated with cancer therapy with increasing intensity. Suggested effects of ovarian tissue transplantation and spermatogonial germ cell transplantation on production of gametes (green area under curve) are shown.
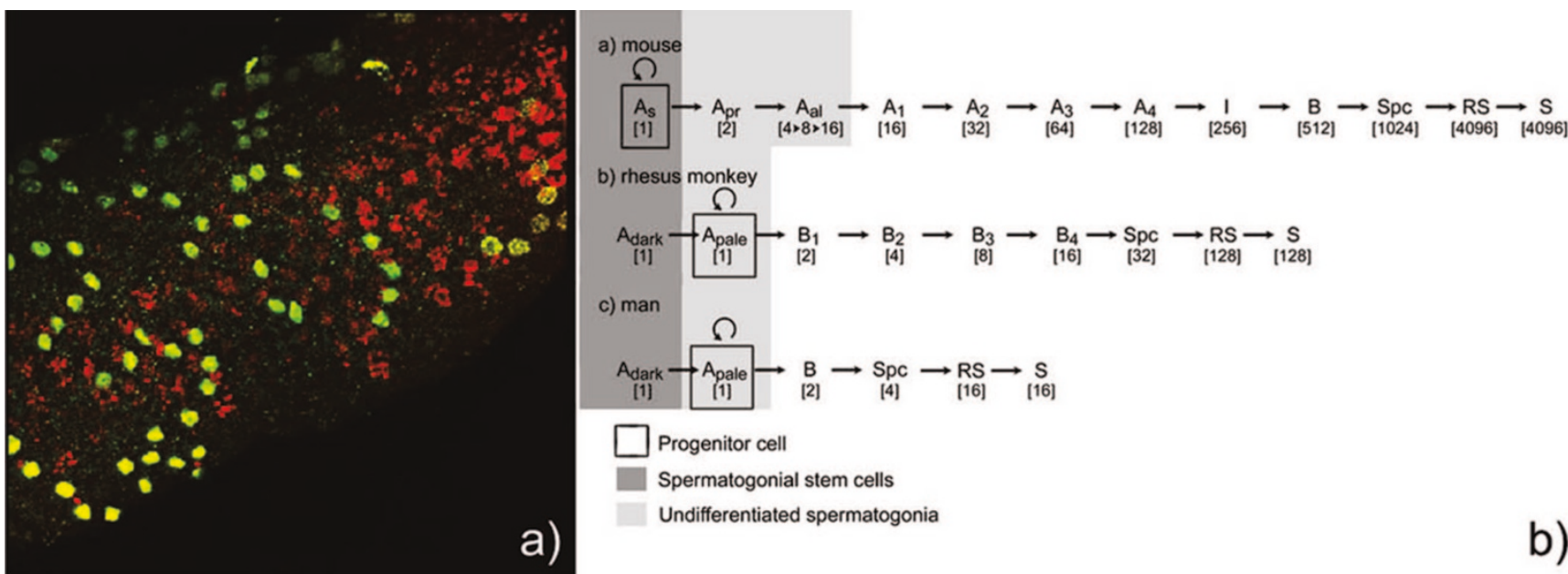

Figure 2. A) Wholemount tissue of adult rhesus monkey seminiferous tubule showing proliferating $\mathrm{B}_{3}$ spermatogonia (Green/yellow: anti-BrdU) and elongating spermatids (red: anti-acrosin) at stage IV of the seminiferous epithelium. B) Comparative scheme illustrating the different types of germ cells in spermatogenesis in mouse, rhesus monkey and man, indicating which germ cell types are currently considered spermatogonial stem cells, undifferentiated spermatogonia and progenitors. Note that in the mouse, the $\mathrm{A}_{\text {single }}$ acts as both spermatogonial stem cell and progenitor; while in primates, these two functions are assigned to two different germ cell types.

\section{DIFFERENCE IN GERMLINE STEM CELL BIOLOGY IN PRIMATES AND RODENTS AND THEIR INFLUENCES ON THE INTERPRETATION OF ANIMAL EXPERIMENTS}

Six different types of spermatogonia have been identified in the rhesus monkey $(10,12-15,27)$ : $A_{\text {dark }}$, $A_{\text {pale }}$, and $B_{1}$ through $B_{4}$ spermatogonia. $\mathrm{A}_{\text {dark }}$ are considered to be the spermatogonial stem cells, $\mathrm{A}_{\text {pale }}$ are undifferentiated spermatogonia, and $\mathrm{B}_{1-4}$ are differentiating spermatogonia (Fig. 2). In men, only three types of spermatogonia have been described: $A_{\text {dark }}, A_{\text {pale }}$ and only one generation of B spermatogonia (Fig. 2). In contrast, in the mouse, seven types of A-spermatogonia and one $\mathrm{B}$ have been defined $(16,17): A_{\text {single }}$ (spermatogonial stem cells); $A_{\text {pair }}$, and $A_{\text {aligned }}$ (undifferentiated spermatogonia); $\mathrm{A}_{1}, \mathrm{~A}_{2}, \mathrm{~A}_{3}, \mathrm{~A}_{4}$, and $\mathrm{B}$ (intermediate or differentiating spermatogonia). (Fig. 2).

The key difference between the spermatogonial organiza- tion in rodents and primates is not based on numbers or subtype distinction, but in the fact that in primates, the $\mathrm{A}_{\mathrm{dark}}$ acts as a true reserve stem cell and the $A_{\text {pale }}$ as progenitor. In rodents, these two functions are combined in one cell type, $\mathrm{A}_{\text {single }}$ (Fig. 2). This important difference is probably the reason why cytotoxins and irradiation have differing effects in rodent and primate testes. Experimental methodology and reproductive concepts derived on the basis of rodent studies are often not transferable to primates, or into a clinical setting. These observed differences reinforce the need to validate any new findings through reproductive studies in primates before introducing new concepts and methods into the clinical environment. The following sections will focus on the rather limited number of preclinical and clinical studies dealing with the effect of cytotoxic treatment, and options to preserve the potential subsequent infertility of the patients. 
Table 1. Review of existing and future approaches for fertility preservation in cancer patients

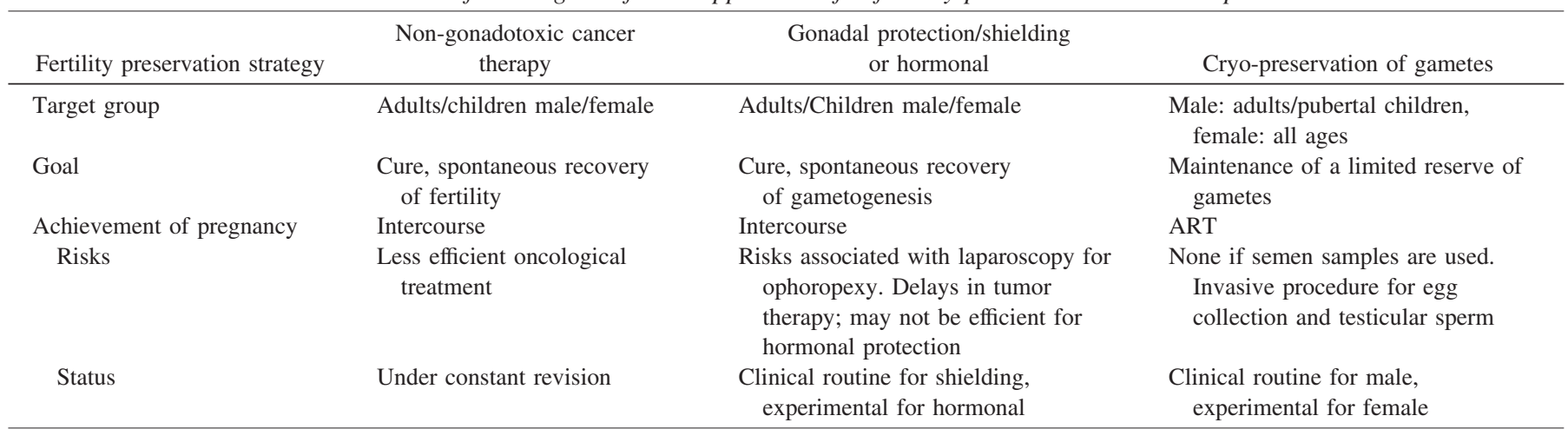

ART, assisted reproduction technology

\section{DIFFERENCES IN GERMLINE STEM CELL BIOLOGY IN FEMALES AND MALES AND THEIR INFLUENCES ON THE EFFECT OF GONADOTOXIC THERAPY}

In general, cytotoxic treatment and irradiation target rapidly dividing cells. It has been known for many years that the testis, especially its rapidly dividing germ cells, is highly sensitive to these treatments. Low doses of cytotoxic drugs or irradiation deplete the differentiating spermatogonia, while less sensitive spermatogonial stem cells survive, and spermatocytes and spermatids continue their maturation to sperm (28). In sexually mature men, testicular involution is a slow process lasting several weeks until temporary or permanent azoospermia is attained. In the human and primate testis, the exact mechanism of recovery from this damage is uncertain, but appears to involve the activation of surviving spermatogonial stem cells. The speed of recovery is dependent on the type and dose of cytotoxic drugs, and/or the dose and fractionation of irradiation therapy (29). Stem cells must first re-colonize the seminiferous tubules and then give rise to differentiating germ cells (Fig. 2). In the spermatogenic epithelium of humans, re-colonization can be detected 9-18 mo after dose 1 Gy and more than 4 y after dose 10 Gy $(30,31)$. In humans and primates where spermatozoa may be isolated in testicular biopsies, it has been shown that recovery after severe damage occurs only focally in a few seminiferous tubules. Patients will be permanently infertile if tubules become fully hyalinized or a complete Sertoli cell only pattern is established $(32,33)$. The spermatogenic stem cells are susceptible to this type of damaging insult at all ages, but the full impact on spermatogenesis manifests itself during onset of puberty (34). Observations suggest that major reason for absent recovery of primate spermatogenesis is the lack of stem cells. This finding is contrary to rodent testis, where cytotoxic insult often induces a block to spermatogonial differentiation, which may be reversed by hormonal treatment after genotoxic insult (35).

In the ovary, cytotoxic damage is transmitted differently since germline stem cells are not present in large numbers and do not show significant turnover (3-5). Cytotoxic insult decreases the amount of primordial follicles, and it appears that this pool is never replenished. Severe damage may deplete the entire follicle pool resulting in permanent ovarian failure (36) (Fig. 1). Cytotoxic insult may also hasten the natural decline of primordial follicles leading to premature menopause (36). Younger patients have more oocytes, thus gonadal damage seems to be less severe than in older women. Regular ovulatory cycles can still occur, but the fertility window of young girls is reduced (37). Due to the innate biologic differences between ovaries and testes, gonadotoxic agents affect fertility in men differently than in women. Men are more susceptible to clinical sub-fertility, which may recover with time, whereas women may be at risk of premature menopause (Fig. 1).

\section{NEW CLINICALLY RELEVANT TECHNOLOGIES FOR PRESERVATION OF FERTILITY}

Non-gonadotoxic cancer therapy. Table 1 presents an overview of the current and the potential future applications for fertility preservation in oncological patients, and reviews the status, limitations, risks, advantages, and disadvantages of each procedure. The high risk of gonadal damage is associated with gonadal or total body irradiation and high-dose chemotherapy (37). Optimal cancer treatments, which would directly target the malignant cells, would have no side effects on the gonads. Improved oncological treatment protocols have made progress in this direction. For example, until recently treatment of testicular cancer and Hodgkin disease had strong gonadotoxic side effects. The discovery of cisplatin- and non-alkylating agent-based therapies to treat these diseases offers not only a high cure rate, but also a high probability that patients spontaneously regain their fertility $(38,39)$. Although the protocols are under constant review, presently it is unlikely that the treatment strategies for the most malignant diseases can be improved upon without diminishing their efficacy.

Gonadal protection. Protective effects of shielding or removing testes and ovaries from a radiation field are wellknown (37). Gonadal protection through hormonal suppression is based on the principle that disruption of gametogenesis renders the gonad less sensitive to the effect of cytotoxic drugs and irradiation (40). If proliferation of germ cells in the male and granulosa cells in the female could be hormonally inactivated, they might be less vulnerable to cytotoxic treatment. Unfortunately, all attempts to develop a successful gonadal protection strategy have failed in humans and primate models 
Table 1 cont'd

\begin{tabular}{|c|c|c|c|}
\hline Fertility preservation strategy & Germ cell transplantation & $\begin{array}{l}\text { Testicular/ovarian } \\
\text { xenografting }\end{array}$ & $\begin{array}{c}\text { Testicular/ovarian } \\
\text { autografting }\end{array}$ \\
\hline Target group & Adults/children male & $\begin{array}{l}\text { Male: Infants/children } \\
\text { Female: All ages }\end{array}$ & $\begin{array}{l}\text { Male: Infants/children } \\
\text { Female: All ages }\end{array}$ \\
\hline Goal & Cure, recovery of gametogenesis & $\begin{array}{l}\text { Generation of a limited number of } \\
\text { gametes }\end{array}$ & $\begin{array}{l}\text { Generation of a limited number } \\
\text { of gametes }\end{array}$ \\
\hline Achievement of pregnancy & Intercourse & ART & ART \\
\hline Risks & $\begin{array}{l}\text { Invasive tissue retrieval, malignant cell } \\
\text { transfer }\end{array}$ & $\begin{array}{l}\text { Invasive tissue retrieval, transmission } \\
\text { of foreign DNA and contagious } \\
\text { agents }\end{array}$ & $\begin{array}{l}\text { Invasive tissue retrieval, malignant } \\
\text { cell transfer }\end{array}$ \\
\hline Status & Experimental & Experimental & Experimental \\
\hline
\end{tabular}

(40). It appears that the hormonal down-regulation of the testes does not protect the spermatogonial stem cells from the sonadotropins effects since these cells are not regulated by hormones (41). Recruitment of primordial, and development of primary follicles are not under gonadotropic control (42). Therefore, in primates the elimination of gonadotropic hormones has little or no beneficial effect.

Cryopreservation of gametes. The most reliable and routinely used option for fertility preservation in adult male patients is cryo-preservation of sperm. All pubertal boys with testis volumes above $10-12 \mathrm{~mL}$ are encouraged to donate a semen sample before cancer therapy $(43,44)$. Alternatively, electro-ejaculation or testicular sperm extraction from a biopsy can be used as a source to retrieve spermatozoa for boys unable to ejaculate (33). Expediency in fertility preservation due to urgency for immediate cancer therapy poses a unique issue in these young patients (see discussion on ethical aspects below). Testicular spermatozoa have been of similar value in intra-cytoplasmic sperm injection (ICSI) attempts as those retrieved from ejaculated sperm (45). However, all options for fertility preservation in boys before spermarche remain entirely experimental. No pregnancies have been reported after in vitro maturation of haploid cells harvested from pubertal testes.

Mature eggs have been cryo-preserved successfully, and offspring has been generated by assisted reproduction techniques (ART). In sexually mature adolescent girls, ovarian stimulation and oocyte retrieval might be an option before gonadotoxic exposures. However, the pregnancy rate with frozen-thawed oocytes is low (46). In addition, the procedure requires considerable time and long-term experience is lacking. Therefore, this technique is not recommended as routine application for adolescent girls with cancer $(37,47)$.

Transplantation of gonadal tissue. In recent years, novel tools have been developed using gonadal tissue as a strategy for fertility preservation. Ovarian tissue consisting of maturing oocytes (up to level of primordial follicles) can be removed and stored before gonadotoxic treatment for girls of all ages. Maturation of tissue can be initiated by auto-transplantation of tissue after the cancer has been cured. To date there are no reported pregnancies using immature ovarian tissue. The feasibility of cryo-preservation of cortical strips, and the high number of primordial follicles in the immature ovary would most likely make this approach more successful in girls than has been reported in adult patients $(4,48)$. Storage of ovarian tissue has started in many centers and selection criteria for cryo-preservation of ovarian cortical tissue have been developed $(37,47)$. Alternatively, culture and in vitro maturation of ovarian follicles has successfully been developed in animal models, but the method is still regarded an experimental approach $(49,50)$.

Theoretically, transplantation techniques are likely to be more successful in boys since testicular tissue contains spermatogonial stem cells, which may be activated and recruited into germ cell development. Transplantation might be achieved either by grafting the tissue to an ectopic site where once revascularized the graft can generate sperm, or by isolating and transplanting spermatogonial stem cells back into their niche in the testis where they may recolonize the seminiferous tubules and ultimately generate mature germ cells (51-53). The latter technique is unique as it has the potential to restore natural fertility from a patient's own germ cells (Fig. 2 ). Both strategies have been developed in rodent animal models (54) and show promise for development in clinical application (see below). In contrast to females, in vitro generation of sperm from spermatogonial precursors has not been reported and must be considered non-achievable at the current level of knowledge and technology.

Storage of gametes and gonadal tissue is an important factor to guarantee success of fertility preservation with germ cell transplantation. Cryo-protection with ethylene glycol and DMSO (DMSO) and slow-programmed freezing have been applied clinically for cryo-preservation of ovarian tissue. Fertile oocytes have been obtained, resulting in live births after transplantation $(55,56)$. Due to the absence of good markers and very low numbers, male germline stem cells are best cryo-preserved in an enriched suspension. Alternatively, testicular tissue can be cryo-preserved and used in testicular xeno- and autografting, or subsequently enzymatically dispersed, leading to a single cell suspension, which then can be used in germ cell transplantation (51-53). Crude single cell preparations and fragments from adult testis and testicular fragments from cryptorchid testes from young boys have been cryo-preserved using propanediol, glycerol, ethylene glycol or 
DMSO (57-59). However, none of these studies have assessed the stem cell capacity of the surviving human spermatogonia.

\section{THE POTENTIAL APPLICATION OF THE NOVEL TOOLS FOR FERTILITY PRESERVATION IN A CLINICAL SETTING}

Spermatogonial germ cell transplantation. A clinical trial was initiated at the Christie Hospital in Manchester, UK in 1999 (60) to test the positive effect of germ cell transplantation. Testicular biopsies were obtained from adult males with solid tumors and cryo-preserved as single cell suspensions before cancer treatment. Five years after the initial report, seven out of twelve patients had received a transfer of the cryo-preserved germ cells. Fertility disposition of these men is not described and the follow-up is ongoing (61). Preclinical studies have demonstrated the feasibility of transplanting germ cell suspensions into the testes of nonhuman primates and man $(53,62)$. A study mimicking the oncological depletion of germ cells by local testicular irradiation in monkeys (53) highlights many of the ensuing clinical challenges. Crucial steps for successful re-fertilization are the safe retrieval of sufficient testicular tissue before cytotoxic insults, avoidance of ischemia, cryo-preservation and thawing of cell suspensions or tissue, sorting of tumor cells or enrichment of stem cell spermatogonia, and efficient ultra-sound guided noninvasive transfer of germ cell suspensions into the rete testis.

Testicular xeno-grafting. Grafting of testicular tissue has been experimentally tested as a xeno-approach but no reports are available on autologous grafting. Limited survival of human testicular tissue was shown to occur in xenografts (63). It is quite intriguing that pre-damaged testicular tissue from cancer survivors or transsexual patients showed better survival than tissue from infertile patients with active spermatogenesis. These findings confirmed previous animal studies (54) that grafting of adult testes is less favorable than grafting of immature testicular tissue. Xenografting of fresh or cryopreserved monkey testicular tissue has been shown to be successful. Testicular grafts have shown full spermatogenic development several months after xenografting (64). Live births using spermatozoa from grafted testicular tissue have been reported only in studies using rodents.

Ovarian autografting. Grafting of human gonadal tissue has been more intensively tested in females and has become an experimental tool in several clinics. The first live birth after ovarian grafting was reported in a monkey following heterotopic ovarian transplantation (65). Meanwhile several clinical studies have shown that orthotopic auto-transplantation of cryo-preserved ovarian strips can result in retrieval of fertilization-competent human oocytes (66) and healthy live births $(55,56)$.

\section{RISKS ASSOCIATED WITH GONADAL GRAFTING AND GERMICELL TRANSPLANTATION STRATEGIES}

Risks associated with collecting gonadal material. When performed prior solid tumor treatment, the laparoscopic sampling procedure performed to collect ovarian tissue is not associated with an increased risk for operation complications (67). In a recent follow-up study there were no adverse long-term effects associated with testicular biopsy when performed during orchidopexy on cryptorchid boys (68). Complications associated with gonadal biopsies may vary among leukemic patients. Traumatic lumbar puncture has been shown to be associated with increased risk to leukemia relapse in the CNS (69). This observation raises questions as to whether a similar risk might be associated with testicular trauma at the time of the overt leukemia. Barrier function in testicular vessels resembles that of blood-brain barrier (70) and inoculation of leukemic cells into an immunologic sanctuary site such as the testis could have adverse effect on prognosis of leukemia. Unfortunately, testicular biopsy material collected in the past to detect testicular leukemic infiltration (71) cannot be used to address this question since most of the biopsies were collected after initiation of chemotherapy.

An important point for risk estimation is the availability of an optimized amount of gonadal tissue. The follicle reserve in young girls is known to be larger than in adult women $(4,48)$. In pre-pubertal testes, the absence of differentiating germ cells causes an enriched numbers of stem cells. Pediatric patients may therefore require a smaller amount of tissue for fertility preservation than that needed from adults. On the other hand, due to the reduced size of the gonads in children and the fact that the intense growth phase of the testes has not yet begun, immature gonadal tissue might be at higher risk for damage by the sampling procedures.

The clinical applicability of ovarian transplantation to prevent premature menopause has been demonstrated in sexually mature women having few primordial follicles. Biopsies collected form young girls are most likely to provide sufficient material for germ cell transplantation. Three critical points should be noted. First, at least $60 \%$ of all follicles are expected to be lost during the initial ischemia after transplanting ovarian samples $(48,72)$. Second, primordial follicles have been shown to be unevenly distributed throughout the cortex of the ovary and actual numbers of follicles may vary greatly in multiple samples from same ovary (73). Finally, ovarian grafts are expected to have a limited lifespan. Grafts typically become hormonally active between 3 and 4 mo after transplantation, and so far only few years survival of grafts has been described (74). The limited viability of a graft indicates that re-transplantation should be performed close to the time when conception is desired. The procedure may also require multiple ovarian grafts. Multiple ovarian biopsies and removal of the entire ovary has been used for ovarian sampling for young girls with cancer $(67,73)$. Ovariectomy provides more tissue for transplantation but decreases the total number of oocytes, reducing the possibility for spontaneous recovery of ovarian function. This is relevant in the case of young girls before menarche, who have some prognosis for retaining ovarian activity after total body irradiation (75). Nevertheless, little is known about the effects of removing one ovary on future fertility and age at menopause. A trend toward a younger age at the onset of menopause in women with one ovary has been observed in some studies, but the clinical data are not uniform (76). Since the combined effect of ovarectomy and gonado- 
toxic treatment on ovarian reserve is not known, removal of several ovarian cortical strips rather than the entire ovary is suggested to be the most appropriate cryo-preservation method for young girls (37).

There are no human or primate studies revealing how many spermatogenic stem cells can be retrieved from the prepubertal testis. According to morphologic studies, it is estimated that one testis of a 10 -y-old pre-pubertal boy contains approximately $83 \times 10^{6}$ germ cells. The corresponding figure in a boy less than one year old is $13 \times 10^{6}$ germ cells (77). In the testis of the juvenile rhesus monkey (16-19 mo of age) there are approximately $14 \times 10^{6} \mathrm{~A}_{\mathrm{dark}}$ spermatogonia, all of which are putative spermatogonial stem cells (78). Apparently only a small fraction of them could be collected by standard testicular biopsy. A mean biopsy size of $0.34 \mathrm{~mm}^{3}$, used in the study of Kvist et al 2005 (59), which is 10\% of the testicular volume of the juvenile rhesus monkey, would maximally result in $14 \times 10^{5} \mathrm{~A}_{\text {dark }}$ spermatogonia collected (78). The colonization rate of the slowly cycling primate $A_{\text {dark }}$ spermatogonia (see above) is expected to be much lower than $4 \%$, which is observed in transplantation assays, for morphologically identified rodent stem cell spermatogonia (79). Thus, it is likely that spermatogonial stem cell transplantation is not clinically applicable without a method to expand spermatogenic stem cells or to increase their colonization capacity. Strategies for in vitro expansion of spermatogonial stem cells have only been described in mouse $(80,81)$. It must be noted that success of spermatogonial stem cell transplantation is also dependent on the quantity and quality of stem cell niches in the transplanted testis.

Risks associated with transplantation of gonadal material. The greatest risk with gonadal tissue re-implantation procedures is the possibility of reseeding tumor cells in cured cancer patients. All successful clinical studies with ovarian grafting have so far been done after treatment of adult solid tumors. Although no methods to deplete cancer cells from the tissue grafts were applied, no cancer relapses have been reported. Because a majority of the pediatric tumors have the capacity to spread hematologically, the risk for intra-vascular contamination and gonadal involvement might be significantly increased. Instead of ovarian tissue, a suspension of primordial or primary ovarian follicles could be autografted in plasma clots, thereby allowing a purification step before grafting. This approach has restored estrogenic activity and fertility in a mouse model, but has so far not been used in humans (82). Only an $89 \%$ depletion of breast cancer cells was detected when activated lymphocytes were used as a purification tool in human follicle suspension (83). The purity of ovarian grafts cannot be guaranteed because the sensitivity to detect residual cancer cells in tissue or cell suspension will not be higher than a level of one in $10^{5}$ cells (84). In the pediatric setting auto-transplantation of ovarian tissue, based on the current methods, raises a number of serious concerns regarding the long-term safety of the procedure.

In the case of auto-grafting testicular fragments, risk of relapsing cancer may be even higher since the testis is known to be an immunologically privileged site, harboring contaminated leukemic cells late after initial treatment (85). If testic- ular single cell preparations are used, the option for cell sorting exists. Recent promising results from a leukemic mouse model show that leukemic cell contamination can be eliminated from single cell testicular samples isolated by flow cytometry (FACS). In this model healthy offspring was born after transplantation of FACS sorted germ cells (86). Although the results in the mouse model are promising, there are several clinical concerns with this method. Cell surface marker based purification protocols rely totally on individually verified surface markers. Although some specific spermatogonial markers are reported, many of them have been shown to be shared with leukemic cells (86). Phenotypical variation of surface marker expression by cancer cells may also result in escape from FACS-guided deletion. Recently, we observed that cancer cells could aggregate with germ cells; this could be another way malignant cells might potentially contaminate FACS purified samples (unpublished observations). It is also unclear if the small biopsy sample from young children could provide enough cells for the needed purification steps. The major limiting factor for FACS purification is mostly to be the low detection level of contaminating cancer cells, which at its best is one event among $10^{4}-10^{5}$ sorted cells (87).

Xenografting of testicular fragments to intermediate immunodeficient hosts (nude mice) could serve as a method to detect minimal residual cancer cell infiltration in the grafted material, but may also serve as a mean to differentiate germline stem cells into gametes that may be used for ART. Auto-transplantation to an ectopic site on the patient may also serve the latter purpose, but will not eliminate the risk of cancer cell contamination in the graft. Grafting testicular fragments would require much less testicular material than spermatogonial stem cell transplantation. In this context one unexplored area of research, which must be taken seriously, is the risk assessment associated with the transmission of viruses or other contagious agents via gametes generated in xenografts. Incorporation of foreign DNA or recipient-specific viral information from a temporary host or contagious agents into human germline is unacceptable. Changes in the DNA would manifest in the offspring of the cancer survivors and could potentially lead to tumor induction or any number of unpredictable consequences. Future studies will show if this risk is real, and whether preventive strategies can be developed.

\section{ETHICAL AND OTHER CONCERNS IN FERTILITY PRESERVATION IN CHILDHOOD}

In a child or an adolescent with a cancer diagnosis, the first concern is survival and not preservation of future fertility. However, the management of this latter aspect at the time of diagnosis is ethically problematic particularly in younger age groups, given the time constringency in the onset of cancer treatment and the problems with obtaining informed consent from children. At the present stage no promises can be made at the individual level that cryo-preserved gonadal tissue will ever be functional as a source of germline stem cells. Another important ethical aspect is the question of legal ownership and rights applying to the banked ovarian and testicular material 
containing gametes or potential gametes. The legislation, if any, on this issue may vary in different countries but should develop as modernized laws emerge.

The use of the cryo-banked tissues and cells is governed by parental decisions, albeit of restricted legal validity. In young children, parental consent should not be static and should be reviewed regularly. If technical developments change the prospects of the fertility preservation plan, amendments should be possible. The child must be involved in increasing degrees as the child's autonomy grows until finally he/she can make informed decisions as a fully responsible adult (88).

The transplantation techniques for gonadal tissues and cells require multi-disciplinary approaches available at the university hospital level. These activities, though costly, are dependent on skilled basic scientists working along with dedicated clinicians. Rapid technical development and high level of activity in the field of ART give hope that we will soon have a more solid evidence base to back our decisions.

Acknowledgments. The authors thank Scott Heregenrother for assistance in language editing.

\section{REFERENCES}

1. Robey PG 2000 Stem cells near the century mark. J Clin Invest 105:1489-1491

2. Holtzer H 1978 Cell lineages, stem cells and the "quantal" cell cycle concept. In:. Lord BI, Potten CS, Cole RJ (eds) Stem cells and tissue homeostasis / Second Symposium of the British Society for Cell Biology. Cambridge University Press, New York, pp 1-28.

3. Zuckerman S, Baker TG 1977 The development of the ovary and the process of oogenesis. In: Zuckerman S, Weir BJ (eds) Ovary. Academic Press, New York, pp 41-67.

4. Faddy MJ, Gosden RG, Gougeon A, Richardson SJ, Nelson JF 1992 Accelerated disappearance of ovarian follicles in mid-life: implications for forecasting menopause. Hum Reprod 10:1342-1346

5. Tilly JL 2001 Commuting the death sentence: how oocytes strive to survive. Nat Rev Mol Cell Biol 2:838-848

6. Hubner K, Fuhrmann G, Christenson LK, Kehler J, Reinbold R, De La Fuente R, Wood J, Strauss JF 3rd, Boiani M, Scholer HR 2003 Derivation of oocytes from mouse embryonic stem cells. Science 300:1251-1256

7. Johnson J, Canning J, Kaneko T, Pru JK, Tilly JL 2004 Germline stem cells and follicular renewal in the postnatal mammalian ovary. Nature 428:145-150

8. Johnson J, Bagley J, Skaznik-Wikiel M, Lee HJ, Adams GB, Niikura Y, Tschudy KS, Tilly JC, Cortes ML, Forkert R, Spitzer T, Iacomini J, Scadden DT, Tilly JL 2005 Oocyte generation in adult mammalian ovaries by putative germ cells in bone marrow and peripheral blood. Cell 122:303-315

9. Johnson J, Skaznik-Wikiel M, Lee HJ, Niikura Y, Tilly JC, Tilly JL 2005 Setting the record straight on data supporting postnatal oogenesis in female mammals. Cell Cycle 4:1471-1477

10. Clermont Y, Leblond CP 1959 Differentiation and renewal of spermatogonia in the monkey, Macacus rhesus. Am J Anat 104:237-273

11. Clermont Y 1969 Two classes of spermatogonial stem cells in the monkey (Cercopithecus aethiops). Am J Anat 126:57-71

12. Clermont Y, Antar M 1973 Duration of the cycle of the seminiferous epithelium and the spermatogonial renewal in the monkey Macaca arctoides. Am J Anat 136:153165

13. Kluin PM, Kramer MF, de Rooij DG 1983 Testicular development in Macaca irus after birth. Int J Androl 6:25-43

14. Fouquet JP, Dadoune JP 1986 Renewal of spermatogonia in the monkey (Macaca fascicularis). Biol Reprod 35:199-207

15. Zhengwei Y, McLachlan RI, Bremner WJ, Wreford NG 1997 Quantitative (stereological) study of the normal spermatogenesis in the adult monkey (Macaca fascicularis). J Androl 18:681-687

16. de Rooij DG 1998 Stem cells in the testis. Int J Exp Path 79:67-80

17. Dettin L, Ravindranath N, Hofmann MC, Dym M 2003 Morphological characterization of the spermatogonial subtypes in the neonatal mouse testis. Biol Reprod 69:1565-1571

18. Ehmcke J, Luetjens CM, Schlatt S 2005 Clonal organization of proliferating spermatogonial stem cells in adult males of two species of non-human primates, Macaca mulatta and Callithrix jacchus. Biol Reprod 72:293-300

19. Ehmcke J, Simorangkir DR, Schlatt S 2005 Identification of the starting point for spermatogenesis and characterization of the testicular stem cell in adult male rhesus monkeys. Hum Reprod 20:1185-1193

20. Chuma S, Kanatsu-Shinohara M, Inoue K, Ogonuki N, Miki H, Toyokuni S, Hosokawa M, Nakatsuji N, Ogura A, Shinohara T 2005 Spermatogenesis from epiblast and primordial germ cells following transplantation into postnatal mouse testis. Development 132:117-122

21. Nayernia K, Drabent B, Meinhardt A, Adham IM, Schwandt I, Muller C, Sancken U, Kleene KC, Engel W 2005 Triple knockouts reveal gene interactions affecting fertility of male mice. Mol Reprod Dev 70:406-416

22. Creemers LB, den Ouden K, van Pelt AM, de Rooij DG 2002 Maintenance of adult mouse type A spermatogonia in vitro: influence of serum and growth factors and comparison with prepubertal spermatogonial cell culture. Reproduction 124:791799

23. Feng LX, Chen Y, Dettin L, Pera RA, Herr JC, Goldberg E, Dym M 2002 Generation and in vitro differentiation of a spermatogonial cell line. Science 297:392-395

24. van Pelt AM, Roepers-Gajadien HL, Gademan IS, Creemers LB, de Rooij DG, van Dissel-Emiliani FM 2002 Establishment of cell lines with rat spermatogonial stem cell characteristics. Endocrinology 143:1845-1850

25. Geijsen N, Horoschak M, Kim K, Gribnau J, Eggan K, Daley GQ 2003 Derivation of embryonic germ cells and male gametes from embryonic stem cells. Nature 427:148-154

26. Nagano M, Shinohara T, Avarbock MR, Brinster RL 2000 Retrovirus-mediated gene delivery into male germ line stem cells. FEBS Lett 475:7-10

27. Clermont Y, Leblond CP 1959 Differentiation and renewal of spermatogonia in the monkey, Macacus rhesus. Am J Anat 104:237-273

28. van Alphen MM, van de Kant HJ, de Rooij DG 1988 Depletion of the spermatogonia from the seminiferous epithelium of the rhesus monkey after $\mathrm{X}$ irradiation. Radiat Res 113:473-486

29. van Alphen MM, van de Kant HJ, de Rooij DG 1988 Repopulation of the seminiferous epithelium of the rhesus monkey after X irradiation. Radiat Res 113:487-500

30. Hahn EW, Feingold SM, Simpson L, Batata M 1982 Recovery from aspermia induced by low-dose radiation in seminoma patients. Cancer 50:337-340

31. Anserini P, Chiodi S, Spinelli S, Costa M, Conte N, Copello F, Bacigalupo A 2002 Semen analysis following allogeneic bone marrow transplantation. Additional data for evidence-based counselling Bone Marrow Transplant 30:447-451

32. de Rooij DG, van de Kant HJ, Dol R, Wagemaker G, van Buul PP, van DuijnGoedhart A, de Jong FH, Broerse JJ 2002 Long-term effects of irradiation before adulthood on reproductive function in the male rhesus monkey. Biol Reprod 66:486-494

33. Meseguer M, Garrido N, Remohi J, Pellicer A, Simon C, Martinez-Jabaloyas JM, Gil-Salom M 2003 Testicular sperm extraction (TESE) and ICSI in patients with permanent azoospermia after chemotherapy. Hum Reprod 18:1281-1285

34. Relander T, Cavallin-Stahl E, Garwicz S, Olsson AM, Willen M 2000 Gonadal and sexual function in men treated for childhood cancer. Med Pediatr Oncol 35:52-63

35. Kangasniemi M, Huhtaniemi I, Meistrich ML 1996 Failure of spermatogenesis to recover despite the presence of a spermatogonia in the irradiated LBNF1 rat. Biol Reprod 54:1200-1208

36. Byrne J, Fears TR, Gail MH, Pee D, Connelly RR, Austin DF, Holmes GF, Holmes FF, Latourette HB, Meigs JW 1992 Early menopause in long-term survivors of cancer during adolescence. Am J Obstet Gynecol 166:788-793

37. Wallace WH, Anderson RA, Irvine DS 2005 Fertility preservation for young patients with cancer: who is at risk and what can be offered? Lancet Oncol 6:209-218

38. Brydoy M, Fossa SD, Klepp O, Bremnes RM, Wist EA, Wentzel-Larsen T, Dahl O 2005 Paternity following treatment for testicular cancer. J Natl Cancer Inst 97:15801588

39. Viviani S, Santoro A, Ragni G, Bonfante V, Bestetti O, Bonadonna G 1985 Gonada toxicity after combination chemotherapy for Hodgkin's disease. Comparative results of MOPP vs ABVD. Eur J Cancer Clin Oncol 21:601-605

40. Shetty G, Meistrich ML 2005 Hormonal approaches to preservation and restoration of male fertility after cancer treatment. J Natl Cancer Inst Monogr 34:36-39

41. McLachlan RI, O’Donnell L, Meachem SJ, Stanton PG, de Kretser DM, Pratis K, Robertson DM 2002 Identification of specific sites of hormonal regulation in spermatogenesis in rats, monkeys, and man. Recent Prog Horm Res 57:149-179

42. Zeleznik AJ 2004 The physiology of follicle selection. Reprod Biol Endocrinol $16: 2-31$

43. Bahadur G, Ling KL, Hart R, Ralph D, Wafa R, Ashraf A, Jaman N, Mahmud S, Oyede AW 2002 Semen quality and cryopreservation in adolescent cancer patients. Hum Reprod 17:3157-3161

44. Kamischke A, Jurgens H, Hertle L, Berdel WE, Nieschlag E 2004 Cryopreservation of sperm from adolescents and adults with malignancies. J Androl 25:586-592

45. Baukloh V German Society for Human Reproductive Biology 2002 Retrospective multicentre study on mechanical and enzymatic preparation of fresh and cryopreserved testicular biopsies. Hum Reprod 17:1788-1794.

46. Borini A, Sciajno R, Bianchi V, Sereni E, Flamigni C, Coticchio G 2006 Clinical outcome of oocyte cryopreservation after slow cooling with a protocol utilizing a high sucrose concentration. Hum Reprod 21:512-517

47. Practice Committee of the American Society for Reproductive Medicine 2004 Ovarian tissue and oocyte cryopreservation. Fertil Steril 82:993-998.

48. Oktay K 2002 Evidence for limiting ovarian tissue harvesting for the purpose of transplantation to women younger than 40 years of age. J Clin Endocrinol Metab 87:1907-1908

49. Murray A, Spears N 2000 Follicular development in vitro. Semin Reprod Med 18:109-122

50. Liu J, Van der Elst J, Van den Broecke R, Dhont M 2001 Live offspring by in vitro fertilization of oocytes from cryo-preserved primordial mouse follicles after sequential in vivo transplantation and in vitro maturation. Biol Reprod 64:171-178

51. Brinster RL, Avarbock MR 1994 Germline transmission of donor haplotype following spermatogonial transplantation. Proc Natl Acad Sci U S A 91:11303-11307 
52. Brinster RL, Zimmermann JW 1994 Spermatogenesis following male germ-cell transplantation. Proc Natl Acad Sci U S A 91:11298-11302

53. Schlatt S, Foppiani L, Rolf C, Weinbauer GF, Nieschlag E 2002 Germ cell transplantation into X-irradiated monkey testes. Hum Reprod 17:55-62

54. Orwig KE, Schlatt S 2005 Cryopreservation and transplantation of spermatogonia and testicular tissue for preservation of male fertility. J Natl Cancer Inst Monogr 34:51-56

55. Donnez J, Dolmans MM, Demylle D, Jadoul P, Pirard C, Squifflet J, MartinezMadrid B, van Langendonckt A 2004 Livebirth after orthotopic transplantation of cryo-preserved ovarian tissue. Lancet 364:1405-1410

56. Meirow D, Levron J, Eldar-Geva T, Hardan I, Fridman E, Zalel Y, Schiff E, Dor J 2005 Pregnancy after transplantation of cryo-preserved ovarian tissue in a patient with ovarian failure after chemotherapy. N Engl J Med 353:318-321

57. Brook PF, Radford JA, Shalet SM, Joyce AD, Gosden RG 2001 Isolation of germ cells from human testicular tissue for low temperature storage and autotransplantation. Fertil Steril 75:269-274

58. Keros V, Rosenlund B, Hultenby K, Aghajanova L, Levkov L, Hovatta O 2005 Optimizing cryopreservation of human testicular tissue: comparison of protocols with glycerol, propanediol and dimethylsulphoxide as cryoprotectants. Hum Reprod 20:1676-1687

59. Kvist K, Thorup J, Byskov AG, Hoyer PE, Mollgard K, Yding Andersen C 2006 Cryopreservation of intact testicular tissue from boys with cryptorchidism. Hum Reprod 21:484-491.

60. Radford JA, Shalet SM, Lieberman BA 1999 Fertility after treatment for cancer: questions remain over ways of preserving ovarian and testicular tissue. BMJ 319:935-936

61. Radford J 2003 Restoration of fertility after treatment for cancer. Horm Res 1:21-23

62. Schlatt S, Rosiepen G, Weinbauer GF, Rolf C, Brook PF, Nieschlag E 1999 Germ cell transfer into rat, bovine, monkey and human testes. Hum Reprod 14:144-150

63. Schlatt S, Honaramooz A, Ehmcke J, Goebell PJ, Rubben H, Dhir R, Dobrinski I, Patrizio P 2006 Limited survival of adult human testicular tissue as ectopic xenograft. Hum Reprod 21:384-389.

64. Honaramooz A, Li MW, Penedo MC, Meyers S, Dobrinski I 2004 Accelerated maturation of primate testis by xenografting into mice. Biol Reprod 70:1500-1503

65. Lee DM, Yeoman RR, Battaglia DE, Stouffer RL, Zelinski-Wooten MB, Fanton JW, Wolf DP 2004 Live birth after ovarian tissue transplant. Nature 428:137-138

66. Oktay K, Buyuk E, Veeck L, Zaninovic N, Xu K, Takeuchi T, Opsahl M, Rosenwaks Z 2004 Embryo development after heterotopic transplantation of cryo-preserved ovarian tissue. Lancet 363:837-840

67. Meirow D, Fasouliotis SJ, Nugent D, Schenker JG, Gosden RG, Rutherford AJ 1999 A laparoscopic technique for obtaining ovarian cortical biopsy specimens for fertility conservation in patients with cancer. Fertil Steril 71:948-951

68. Patel RP, Kolon TF, Huff DS, Carr MC, Zderic SA, Canning DA, Snyder HM 3rd 2005 Testicular microlithiasis and antisperm antibodies following testicular biopsy in boys with cryptorchidism. J Urol 174:2008-2010.

69. Rech A, de Carvalho GP, Meneses CF, Hankins J, Howard S, Brunetto AL 2005 The influence of traumatic lumbar puncture and timing of intrathecal therapy on outcome of pediatric acute lymphoblastic leukemia. Pediatr Hematol Oncol 22:483-488

70. Bart J, Groen HJ, van der Graaf WT, Hollema H, Hendrikse NH, Vaalburg W, Sleijfer DT, de Vries EG 2002 An oncological view on the blood-testis barrier. Lancet Oncol 3:357-363

71. Pui CH, Dahl GV, Bowman WP, Rao BN, Abromowitch M, Ochs J, Rivera G 1985 Elective testicular biopsy during chemotherapy for childhood leukaemia is of no clinical value. Lancet $2: 410-412$
72. Aubard Y, Piver P, Cogni Y, Fermeaux V, Poulin N, Driancourt MA 1999 Orthotopic and heterotopic autografts of frozen-thawed ovarian cortex in sheep. Hum Reprod 14:2149-2154

73. Schmidt KL, Byskov AG, Nyboe Andersen A, Muller J, Yding Andersen C 2003 Density and distribution of primordial follicles in single pieces of cortex from 21 patients and in individual pieces of cortex from three entire human ovaries. Hum Reprod 18:1158-1164

74. Roberts JE, Oktay K 2005 Fertility preservation: a comprehensive approach to the young woman with cancer. J Natl Cancer Inst Monogr 34:57-59

75. Sarafoglou K, Boulad F, Gillio A, Sklar C 1997 Gonadal function after bone marrow transplantation for acute leukemia during childhood. J Pediatr 130:210-216

76. Cramer DW, Xu H, Harlow BL 1995 Does "incessant" ovulation increase risk for early menopause? Am J Obstet Gynecol 172:568-573

77. Muller J, Skakkebaek NE 1983 Quantification of germ cells and seminiferous tubules by stereological examination of testicles from 50 boys who suffered from sudden death. Int J Androl 6:143-156

78. Ramaswamy S, Plant TM, Marshall GR 2000 Pulsatile stimulation with recombinan single chain human luteinizing hormone elicits precocious Sertoli cell proliferation in the juvenile male rhesus monkey (Macaca mulatta). Biol Reprod 63:82-88

79. Shinohara T, Orwig KE, Avarbock MR, Brinster RL 2000 Spermatogonial stem cell enrichment by multiparameter selection of mouse testis cells. Proc Natl Acad Sci U S A 97:8346-8351

80. Kubota H, Avarbock MR, Brinster RL 2004 Growth factors essential for selfrenewal and expansion of mouse spermatogonial stem cells. Proc Natl Acad Sci U S A 101:16489-16494

81. Kanatsu-Shinohara M, Ogonuki N, Iwano T, Lee J, Kazuki Y, Inoue K, Miki H, Takehashi M, Toyokuni S, Shinkai Y, Oshimura M, Ishino F, Ogura A, Shinohara T 2005 Genetic and epigenetic properties of mouse male germline stem cells during long-term culture. Development 132:4155-4163

82. Carroll J, Whittingham DG, Wood MJ, Telfer E, Gosden RG 1990 Extra-ovarian production of mature viable mouse oocytes from frozen primary follicles. J Reprod Fertil 90:321-327

83. Schroder CP, Timmer-Bosscha H, Wijchman JG, de Leij LF, Hollema H, Heineman MJ, de Vries EG 2004 An in vitro model for purging of tumour cells from ovarian tissue. Hum Reprod 19:1069-1075

84. Bottcher S, Ritgen M, Pott C, Bruggemann M, Raff T, Stilgenbauer S, Dohner H, Dreger P, Kneba M 2004 Comparative analysis of minimal residual disease detection using four-color flow cytometry, consensus IgH-PCR, and quantitative IgH PCR in CLL after allogeneic and autologous stem cell transplantation. Leukemia 18:16371645

85. Franck P, Duffner U, Schulze-Seemann W, Riede U, Dordelmann M, Niemeyer CM 1998 Testicular relapse after 13 years of complete remission of acute lymphoblastic leukemia. Urol Int 60:239-241

86. Fujita K, Ohta H, Tsujimura A, Takao T, Miyagawa Y, Takada S, Matsumiya K, Wakayama T, Okuyama A 2005 Transplantation of spermatogonial stem cells isolated from leukemic mice restores fertility without inducing leukemia. J Clin Invest 115:1855-1861

87. Hu X, Bessette PH, Qian J, Meinhart CD, Daugherty PS, Soh HT 2005 Markerspecific sorting of rare cells using dielectrophoresis. Proc Natl Acad Sci U S A 102:15757-15761

88. Bahadur G 2004 Ethics of testicular stem cell medicine. Hum Reprod 19:2702-2710 